\title{
Entrevista
}

\section{A psicanálise e a perspectiva ética na contemporaneidade: entrevista com Patrick Guyomard*1}

\section{Psychoanalysis and the ethical perspective} in contemporaneity: interview with

\section{Patrick Guyomard}

Christopher Leclerc*2

Sophie Bergheimer*3

Domingo, 13 de janeiro de 2019. Paris, França.

C.L.: Podemos começar com você se apresentando.

P.G.: Faz 50 anos que sou psicanalista... faz muito tempo! [risos] Pertenci a muitas sociedades, fundei duas, sou atualmente presidente da Sociedade de Psicanálise Freudiana e diretor das Edições Campagne Première. Fui professor na Universidade Paris VII - Diderot. Escrevi alguns livros e artigos, mais particularmente alguns artigos na coleção dirigida por Jacques André, Les Petits Bleus, da Presses Universitaires de France (Guyomard, 2009a, 2009b, 2012). Além disso participei do primeiro Comité de Ética, de forma alguma como membro estatutário,

*1 Traduzida por Lisley Braun Toniolo, revisada por Andréa Máris Campos Guerra e Cristina Lindenmeyer. C.L.: Christopher Leclerc; S.B.: Sophie Bergheimer; P. G.: Patrick Guyomard.

*2,3 Université Paris VII Didreot, Université de Paris (Paris, França). 
mas como debatedor, em particular participando dos debates nos quais os psicanalistas eram convocados. Trabalhei em um órgão, em uma missão de pesquisa no Ministério da Saúde, e então dirigi, acompanhei e avaliei certo número de projetos de pesquisa, em particular os primeiros projetos de pesquisa sobre a ética médica, seguidos da avaliação dos Comitês de Ética nos diferentes hospitais e nas diferentes instituições. Enfim, escrevi um livro sobre a ética (Guyomard, 1998).

C.L.: Como você veio a trabalhar com essa questão da ética?

P.G.: Penso que vim a trabalhar com a ética por dois meios bastante diferentes. Um deles, digamos, mais interno à psicanálise, e em continuação às posições e às obras de Lacan. A questão da ética é apresentada desde Freud. Ele diz que a ética é uma maneira de se destrinchar na vida, enfim, não me lembro mais muito bem de sua expressão. $O$ tema não é secundário para Freud, mas muito pouco problematizado. A posição de Freud em relação à ética está ligada ao fato de que para ele havia a ética dos praticantes e a dos cientistas de seu tempo, quer dizer que haviam certos valores, coisas que se fazia e coisas que não se fazia. Ou seja, uma forma de estar em relação, de se pensar a relação com os pacientes.

Por exemplo, no momento em que ele explica porque renunciou à hipnose, tem a necessidade de dizer que uma de suas razões, a primeira, é que nem todo mundo era hipnotizável, mas outra razão é que ele não suportava ter esse tipo de poder sobre seus pacientes, o de colocá-los em tal estado de sugestão. Essa situação the parecia, no fundo, bastante indigna, podemos dizê-lo assim. Depois, a segunda razão, é que ele não queria que a psicanálise fosse uma visão de mundo (Freud 1933/1989), ele não queria ser um profeta. Recusava-se absolutamente a que deduzíssemos através da psicanálise coisas que a psicanálise não poderia abordar.

As referências éticas estavam ligadas ao seu trabalho de médico, mas, também, a de cientista. Em outras palavras, é necessário certa dedicação em seu trabalho, incluindo os riscos que o pesquisador pode ele mesmo ter, como todos os grandes pesquisadores: físicos, químicos, biólogos, que faziam experiências às vezes colocando em perigo suas vidas. Alguns puderam sofrer as consequências - aqui penso nos químicos, em um químico em particular, Laplace, a quem Freud cita com frequência. Ele fazia manipulações nos laboratórios, experiências que às vezes explodiam, às vezes ele era ferido, bem... podemos pensar também nos primeiros pesquisadores sobre a radioatividade. 


\section{ENTREVISTA}

Quer dizer que existe a ideia de dedicação. O fato de se dedicar a qualquer coisa e de aceitar os riscos, quase em um registro de paixão. É como um amor pela verdade, como um amor da verdade científica, na procura pela exatidão. Assim, a inscrição em uma comunidade científica, ao mesmo tempo interna a seu campo, mas também externa a seu campo, se faz na exigência de discussões, de debates, de esclarecimentos, de exposição de resultados, oferecendo-se à crítica e à discussão. Ou seja, todos os textos de Freud, as conferências de introdução à psicanálise etc., não são simplesmente para explicar aos outros o que era a psicanálise. Certamente é uma defesa e uma ilustração da psicanálise mas, ao mesmo tempo, era um dever - que, neste caso, nomearei ético — de se expor, de se oferecer às críticas e de recusar a sua paralisia.

Era essa a ética de Freud. Poderíamos nos perguntar: "A psicanálise o conduziu a uma ética particular ou a uma ética suplementar?" Penso que nenhuma das duas. Ele respeitava certo número de regras que ele não devia de forma alguma à psicanálise, mas que eram as regras éticas, pode-se dizer morais, de seu tempo. Essa é a posição de Freud.

Lacan mudou um pouco as coisas. De início, Lacan (1959-1960/1986) fez um seminário sobre a ética da psicanálise, seminário que ele mesmo considerava muito importante. Trata-se de um seminário que ele sempre quis retomar, reescrever, mas que jamais o fez. Isso indica que, para ele, era um seminário essencial e que, no mesmo movimento, ele não estava completamente satisfeito com o resultado a que havia chegado. Isso faz com que, na obra de Lacan - Lacan que eu conheci, com quem trabalhei uma dezena de anos - houvesse manifestadamente uma referência ao que ele mesmo havia chamado de ética.

No fim das contas, Ética da psicanálise foi que deu título a esse sétimo seminário anual que ofereceu. O objetivo desse seminário é muito claro, falaremos disso daqui a pouco se quiser. A questão é saber: em que essa ética resulta? Ou, em suma, qual é o valor, o Bem — com um B maiúsculo que pode servir de referência, de bússola, de orientação? Ou seja, em nome de quem podemos avaliar, julgar, decidir alguns atos, posições, abstenções?

Dito de outra forma, a questão para Lacan é: será que a ética da psicanálise permite, em sua prática e além de sua prática - digo além de sua prática porque isso concerne, naquele momento, à posição da psicanálise na cultura e ao que ela viria a trazer de específico à cultura — orientar sua ação?

Assim, esse seminário, que é um seminário de 1960, efetivamente muito importante, no qual Lacan debate uma enormidade de questões, é um 
seminário que se conclui pela análise da tragédia de Sófocles, Antígona. Esse texto é uma espécie de discussão para saber, simplesmente, se Antígona é admirável ou não. E, se ela é admirável, em que ela o é. Mas, também, se ela é um exemplo ou até mesmo um ideal. E é nesse momento que surge no seminário de Lacan essa frase, que é uma frase de referência — ainda que ela seja utilizada de forma bastante distinta por todos aqueles que se referem a Lacan — e que se trata de "a única coisa da qual se pode ser culpado é a de ceder de seu desejo" (Lacan, 1959-1960/1986).

E dali se difundiu no meio analítico uma espécie de máxima que não se encontra no seminário de Lacan, mas que foi apreendida, alimentada, realçada por certos alunos de Lacan e por certos analistas que afirmavam ser originalmente de Lacan, que é de não ceder de seu desejo. Como uma máxima que poderia orientar a ação em nome do valor do desejo, como uma espécie de máxima que poderia orientar a conduta de qualquer um em diferentes situações. Como se, em síntese, existisse — digo isso de forma hipotética — uma máxima ética da psicanálise que seria "não ceder de seu desejo".

Então essa máxima, anunciada em 1960, que nessa época não teve de fato tanta repercussão no campo analítico, no início dos anos 1980 — no fim 690 dos primeiros anos de prática de Lacan e depois com sua sucessão — ela se tornou emblemática do que Lacan teria "aconselhado". Assim surgiu na corrente lacaniana essa questão do desejo, uma ética do desejo, uma ética que coloca o desejo como valor supremo. Como uma referência suprema e que, por consequência, como referência suprema, poderia justificar e fundar toda prática, mesmo eventualmente contra as leis, além das leis, de todas as leis, políticas, é claro. Então, em nome do desejo, poder-se-ia estar além das leis ou fora da lei, dependendo apenas do que você decidisse.

É esta toda a questão de Antígona, questão clássica, filosófica, política, moral etc. Em suma, não é tanto a questão de sua posição pessoal na tragédia de Sófocles que interessa, mas sim como um exemplo para pensar essas questões. Assim ela é exemplar? Mas do que ela é exemplar? Certamente ela é exemplar porque é uma heroína. Sófocles a vê como figura heroica, emblemática, uma figura muito marcada por aquilo que os gregos chamavam hubris, que podemos traduzir hoje mais ou menos - penso ser justo como orgulho, no sentido de que o orgulho é aquilo que permite ultrapassar qualquer coisa.

E, nesse significante do orgulho, penso que escutamos muito bem, sobretudo em francês, quer dizer être fier. Orgulho é, ao mesmo tempo, orgulhoso — em português brasileiro (fierté) e être fier, podemos dizer 


\section{ENTREVISTA}

"sou orgulhoso de ser brasileiro" e ao mesmo tempo empregamos a palavra orgueilleux [orgulhoso]. Na palavra orgulho, há aspectos muito narcisistas, uma coisa orgulhosa demais, algo bastante negativo: é alguém que não se submete e, então, que se revolta, quando pensamos que ele faria bem ao se submeter.

Assim isso interroga um pouco toda essa zona que é de uma importância certamente bíblica e teórica, política, ética também. Então, qual é a exemplaridade de Antígona? Basicamente é um tipo de santa que recusa, que vai além, que não faz nenhuma concessão. Ao mesmo tempo é uma vítima que se sacrifica e que destrói tudo. É essa a questão de Antígona: existe efetivamente uma oposição entre as leis escritas e as leis não escritas. Mas será que as leis não escritas se referem à revolta de um sujeito singular que não quer se inscrever em uma comunidade?

Bom, esta reflexão faz parte da minha história na psicanálise. Escrevi, aliás, um livro sobre essa questão — La jouissance du tragique [O gozo do trágico] (Guyomard, 1992) — que visava um pouco esclarecer essa questão de não aderir completamente, cegamente, se posso dizer, à simplificação da frase de Lacan, quer dizer, não levar em conta a primeira parte da frase de Lacan. Porque, basicamente, a frase de Lacan é "A única coisa da qual podemos ser culpados é a de ceder de seu desejo". Assim, se a gente lê aproximadamente o francês, isso quer dizer que não ceder de seu desejo é esperar uma situação na qual não seremos jamais culpados. Será que não seremos jamais culpados? Deve-se buscar uma posição na qual nos exoneramos, nos extraímos de toda culpabilidade, tentando alcançar um estado de pureza ou um estado de inocência ou, ainda, um estado no qual estaríamos em completa adesão conosco mesmo?

De um lado, isso pode ser bem entendido por alguém que resolveu uma crise, que tomou uma decisão, podemos dizer que está em adequação consigo mesmo. E que também atravessou, certa culpabilidade, no sentido de que essa culpabilidade poderia lhe conter, lhe impedir, lhe restringir não querer fazer o mal, não pensar sobre isso, não pensar sobre aquilo. Ao mesmo tempo, nessa noção de culpabilidade não se deve inscrever outro registro, que é o registro da responsabilidade, da solidariedade com os outros, do pertencimento a um mundo humano e a um grupo humano, e de uma responsabilidade compartilhada, de decisões compartilhadas?

E no fundo, querer se exonerar de toda culpabilidade, não é querer se exonerar de toda responsabilidade? Quer dizer que uma reflexão ética é uma reflexão que tenta inscrever uma reflexão sobre a responsabilidade de nossas 
ações, ao mesmo tempo, se dizemos como máxima que não se pode ceder de seu desejo para não se sentir culpado, nesse momento nos exoneramos de toda responsabilidade, até mesmo da possibilidade de dizer "eu errei". Essas são as questões que trabalhei no meu livro. Essa reflexão em Lacan é contínua, ela tem uma história. Lacan retoma Antígona, ele tem outras posições em relação à ética, enfim, não é o objeto de nossa discussão esta noite, mas isso também existe.

Enfim, o outro ponto que me fez interessar por essas questões é que a psicanálise, basicamente, se tornou uma referência graças a Lacan — isso é preciso dizer — , quanto à reflexão sobre o que é o simbólico e sobre o que é o humano. E uma referência científica, quer dizer não uma referência religiosa, uma referência antes laica em seu conjunto. Então, quando as questões éticas são postas em nossa sociedade - quer dizer, antes mesmo da constituição oficial do Comitê Nacional de Ética sob seus diferentes aspectos, e que certamente continua a cumprir o trabalho que conhecemos — , houve vários comitês, pré-comitês, nos quais havia principalmente juristas, antropólogos e historiadores.

Juristas, pois há uma referência ao Direito. Antropólogos, pois há uma 692 referência à antropologia humana: o que é um ser humano? Quais são os dados e as configurações simbólicas nas quais eles se inscrevem? E depois, dados históricos, pois em suma o Comitê Consultivo de Ética deve sua origem aos efeitos das descobertas científicas sobre o humano, sobre os efeitos do progresso científico. A partir do momento no qual constatamos esse progresso, constatamos que ele é, ao mesmo tempo, benéfico, mas cujos limites não vemos muito bem. E que pode até mesmo, em certos momentos, colocar em causa as representações que temos de alguns de nossos valores, quer seja a família, quer seja o que é ser pai, o que é ser criança, coisas como essas. Então, entramos em uma evolução, aceitamos uma evolução, aceitamos que houve mudanças.

Assim a história, entre outras, é algo que pode nos permitir pensar essas evoluções e ter referências. Há demasiadas coisas que mudaram. O que pode mudar? O que não pode mudar? O que os historiadores podem dizer sobre isso? Os antropólogos, aliás, os juristas também porque há evoluções do direito, os antropólogos seriam mais no sentido de: o que não deve mudar? Isso quer dizer que, através da diversidade das sociedades nas quais há diversidades de alianças, de práticas, de filiações — alguém como Lévi-Strauss nos advertiu, nos esclareceu que há a diversidade de sistemas de aliança - , mas talvez também a universalidade de um núcleo em torno da 


\section{ENTREVISTA}

troca e do incesto que é sempre o mesmo. E os psicanalistas se encontram no cruzamento de todas essas questões, ao mesmo tempo porque elas se referem forçadamente à antropologia e, ao mesmo tempo, elas se referem clinicamente à história de indivíduos singulares, pois, basicamente, nossa prática nos confronta clinicamente às singularidades...

É a partir disso que os psicanalistas foram convocados a participar das primeiras reflexões dos pré-comitês — comitês que precederam o Comitê Nacional de Ética, pois a psicanálise se tornou uma referência. E perguntaram aos psicanalistas o que eles pensavam, as opiniões que tinham a dar e quais eram, em suma, os fundamentos em jogo, como poderíamos pensar as mudanças ou a falta de mudança. E assim, houveram alguns psicanalistas, inclusive eu, que foram convocados, quer dizer, convocados a dizer nossas opiniões sobre as questões éticas que, no início e naquele momento, era principalmente a PMA (Procriação Medicamente Assistida). Tratava-se, nesse começo, do destino das crianças nascidas sob PMA. Havia questões que, imediatamente, tinham um impacto político, quer dizer: uma mulher pode dispor de seu corpo? Seu corpo lhe pertence? O que é uma criança? O que é o direito das crianças? $\mathrm{O}$ que nós psicanalistas sabemos, que retornos nossa clínica nos permite ter sobre estas práticas?

Trata-se de uma questão bastante aberta e bastante complicada. Em todo caso, porém, pessoalmente, já que fui implicado lá dentro, aceitei participar. Alguns colegas psicanalistas, por razões absolutamente louváveis e defensáveis, diziam: "Mas nós não temos nada a dizer, não é a nós que cabe dizer alguma coisa" ou "nossa posição é outra, ela é neutra, extraterritorial". Essa não era completamente a minha posição, assim me impliquei em algumas discussões efetivas e, por consequência, isso me mobilizou, se posso dizer, nas reflexões sobre a ética.

C.L.: Em relação a essa singularidade, Lacan pôde anunciar essa frase um pouco - na minha opinião - um pouco obscura, de dizer que o inconsciente, em si mesmo, tem um estatuto que é ético?

P.G.: Sim, efetivamente. Fui muito marcado por essa frase de Lacan, que pode parecer um pouco curiosa, e que é justamente "o inconsciente tem um estatuto ético". Parece-me que é muito forte, que é um pouco espantoso e até mesmo um pouco brutal, mas essencial. Por que, basicamente, é uma frase que, de um lado, diz que não poderemos jamais objetivar o inconsciente, que, essencialmente, conhecer o inconsciente e reconhecê-lo está no mesmo movimento, e que não podemos conhecer o inconsciente, se não o 
reconhecemos. Não poderemos jamais reduzir o inconsciente a um objeto, a uma coisa experimental, separada das condições de uma experiência e de certo número de reflexões. Pois há qualquer coisa de inconsciente que, de certa forma, restará sempre desconhecida. E, por consequência, o inconsciente é reconhecível, e conhecível, através da implicação e do engajamento do analista - que se engaja em um tratamento.

É por isso que digo que conhecer e reconhecer o inconsciente é a mesma coisa. E que, por consequência, o inconsciente em questão não é separável disso que representa o psicanalista. Então, que os psicanalistas tenham uma posição ética, isso pode fazer parte do reconhecimento do inconsciente. E a posição de Lacan é muito clara. Em outras palavras, isso revela uma decisão, a ética se torna uma decisão. Ética quer dizer escolha, decisão e referência a certo valor.

Qual é o valor nesse caso? E a fala de alguém. A partir do momento em que escutamos alguém falar, numa análise ou fora dela, e damos importância ao valor da palavra - a isto que alguém diz, a isso que não pode dizer, isso que não diz, isso que ele diz sem dizer, toda essa dimensão - , estamos confrontados a uma questão do reconhecimento da palavra. E, nesse momento, em nome desse valor tomamos uma decisão.

Isso quer dizer também que podem existir muitas práticas nas quais se decide não levar em conta o inconsciente, o que significa que decidimos não levar em conta a fala das pessoas como faz um psicanalista e reduzimos sua fala a "questões-respostas". Ou bem quando as práticas são por demais científicas, por exemplo codificáveis pelas medidas — como as análises de dados quantificados - não temos mais necessidade de falar com as pessoas, nem mesmo a necessidade de escutá-las.

S.B.: Para retomar e recuperar o que você acaba de dizer - porque penso que você propôs uma resposta à reflexão da ética da psicanálise para além de sua prática, gostaríamos de saber: como você viveu essa experiência? Como você situa a presença do psicanalista e da psicanálise no seio de um Comitê de Ética?

P.G: A presença de um psicanalista, podemos situá-la de diferentes formas. Por um lado, ela seria guardiã do valor dado à fala daqueles que se encontram implicados em vários níveis nas decisões médicas (ou quem demanda, ou quem sofre seus efeitos, ou quem discute). Como psicanalistas, seríamos guardiões do valor da fala. E guardiões a título da pesquisa com essas pessoas, acerca do que elas têm a dizer certamente, mas também de seus 


\section{ENTREVISTA}

desejos e de suas expectativas, no sentido de melhor lhes permitir tomar as decisões ou fazer escolhas que possam assumir.

Fundamentalmente é isso: melhor lhes permitir fazer as escolhas que eles possam assumir, o que imediatamente supõe que se desejamos que as escolhas sejam assumidas, se elas forem arriscadas, se elas forem indeterminadas enfim, indeterminada eu quero dizer abertas aos imprevistos científicos, quer dizer, por exemplo no caso de surdez, de implante, se não sabemos se isso vai funcionar ou não - em todo caso, que os sujeitos assumam sua escolha porque assim se portarão melhor. Dessa forma ele instala seu lugar de responsabilidade nessa decisão e sua participação no processo.

Quer dizer que não os informamos simplesmente a título de um saber do que vai se passar, das consequências que isso vai ter etc. Porém que lhes deixemos o tempo, em um diálogo com alguém, de refletir melhor sobre seu desejo - certamente com os limites temporais — sobre o que é essencial para ele, sobre o que eles têm necessidade de salvar, as escolhas que querem fazer. E quem diz escolha diz várias opções, e quem diz várias opções diz capacidade de mensurar a mais importante, mesmo se for a mais dolorosa. Se queremos absolutamente que uma criança atingida por surdez possa falar, se pensamos que isso é um valor, como faremos para conduzi-la até lá, para nos conduzirmos nós mesmos até lá, e para aceitar correr os riscos e fazer escolhas nas melhores condições possíveis? Então isso é verdadeiramente algo com a qual os analistas podem contribuir.

Há algo a mais com que eles podem contribuir e que é um pouco estranho. É que, como analistas, vocês o sabem, trabalhamos muito com os efeitos a posteriori. Quando perguntamos a F. Dolto se ela era a favor ou contra a PMA, ela respondeu: "Eu não sou nem a favor nem contra, eu não tenho nada a dizer. Quando tiver pacientes que são nascidos por PMA e que eu os tiver escutado, nesse momento poderei dizer alguma coisa sobre o fato de me fundamentar sobre a fala de pessoas que passaram por isso, e sobre sua experiência".

Então isso supõe uma dimensão temporal a posteriori, o fato de que não sabemos de imediato. Imediatamente, não é possível. Claro que, com as capacidades de ajustamentos, mas também com as capacidades de retorno e de não retorno, isso introduz alguma coisa como um tipo, no fundo de desconhecido, no seio de muitas ações. E sobre a dificuldade, em muitas ações, de possuir uma certeza total e completa de $100 \%$ disso que fazemos. Eis então que, fundamentalmente, esta é uma forma de retomar a questão ética: a ética se coloca quando não temos certeza. Quando temos certeza, 
não é uma questão de ética, mas uma questão de metodologia: fazemos isso assim ou assado - mas temos certeza. Quando não temos certeza se é uma boa decisão, ou quando não sabemos onde essa decisão pode levar, nesse momento a questão se coloca: faremos ou não o faremos?

E tentamos avaliar os benefícios, a causa, as perdas etc. Assim, desse ponto de vista, o analista, que não é um especialista do desconhecido, mas um guardião — um guardião reservado, modesto porque não — da parte desconhecida e imprevisível que esta presente em cada ação, será também um guardião do desconhecido e do imprevisível, quer dizer da lembrança do fato de que todas as decisões médicas são também decisões que comprometem os humanos. Isso quer dizer que são situações que concernem aos seres humanos, às mulheres, aos homens, às crianças, e que esses não podem jamais ser eliminados ou afastados.

C.L.: Talvez uma outra questão que se extrai um pouco disso que preparamos é: a noção de ética ela mesma, como ela é colocada, viria interrogar algo do lado do saber do analista? E neste caso...

P.G: Mas você diz isso em relação ao analista ou em geral?

\section{C.L: Em relação ao analista.}

P.G: Sim.

C.L: Principalmente do saber do psicanalista, penso que seria sobretudo isso. Nesse caso, qual saber? Se é um saber sobre o desejo, em que a ética interroga o saber da psicanálise sobre o desejo?

P.G: É uma boa questão, mas um pouco complicada. De maneira geral, Lacan, fundamentalmente, sustentou uma tese, uma oposição que ele exprime, creio que em 1966: na análise, é o desejo do analista que — não me lembro exatamente da frase - mas que orienta as coisas, em última instância. Assim, concernente à psicanálise que é uma prática da palavra, isso diz simplesmente tudo. Não é simples dizê-lo, a partir do momento em que a questão do desejo é aberta, quer dizer, a partir do momento em que a questão "o que é que alguém deseja?" entra na dialética do desejo, esta questão é automaticamente ligada a: "o que desejam de mim?".

É isso que significa. Impossível avançar na questão "o que eu quero?" sem que essa questão seja tomada, de certa forma desde sempre, na questão que é "o que desejam de mim? O que esperam de mim? O que querem de mim?". Então, isso que desejam de mim, isso pode designar o que, em termos analíticos, chamamos de supereu. Isso pode designar os pais, pode designar 


\section{ENTREVISTA}

a cultura, a tradição, a moral, tudo aquilo que queremos; dito de outra forma, disso que constitui um sujeito e nisso que ele tem de se inscrever e tomar a palavra. Existe a fórmula de Lacan: "O desejo é sempre o desejo do Outro". Então, interrogar seu desejo é interrogar o desejo do Outro.

Vemos bem nas histórias como muito claramente as expectativas e desejos familiares dos pais são para as crianças, ao mesmo tempo, um apoio e um tipo de coação aprisionante. Como todos os laços, os laços ligam e, concomitantemente, amarram. É bom estar amarrado porque dessa maneira ficamos tranquilos? Mas, ao mesmo tempo, estamos ligados. Quando dizemos "estou ligado a alguém", não estamos de maneira alguma sozinhos. Mas, concomitantemente, se estamos amarrados, podemos mexer, viver, partir etc.?

Eis então essa espécie de dialética. Assim, nessa base que é aceitável para todo mundo, Lacan é alguém que coloca de início a prioridade do desejo e a prioridade da palavra. O que quer dizer que todo ser humano, aqui compreendido na psicanálise, tenta se ajustar a isso que se espera dele. Dito de outra forma, toda análise, para uma pequena parte, em um dado momento, cruza a questão: "o que o analista espera de mim?". Assim essa fórmula "o que esperam de mim" é, ao mesmo tempo, algo que permite fazer uma análise, mas também algo que impede de fazer uma análise, pois imaginamos que o analista também espera qualquer coisa precisa.

Há bem um momento no qual é preciso se desligar disso e se perguntar o que nós mesmos queremos, porque a análise permanece um empreendimento de desalienação ou, de certa forma, de liberação, quaisquer que sejam suas raízes. Conhecer as raízes, isso não é forçosamente ser prisioneiro. A vida de Freud o ilustra. Freud é oriundo de uma família judia do lado de sua mulher e de seu próprio lado, tradicional com avós rabinos dos dois lados, ainda mais na família de sua mulher do que na sua. Ainda assim, em particular o pai de Freud, saíram de um meio - não verdadeiramente de um gueto - , mas de um meio bastante fechado, ele quis se emancipar, se liberar, entrar na vida, empreender.

Ao mesmo tempo, porém, ele fez estudos científicos, se inscreveu como pesquisador, se inscreveu na sociedade vienense. O pai de Freud lhe deu sua Bíblia, quer dizer a Bíblia de Philipson, isto é muito forte e muito interessante. Freud viveu de uma só vez como homem da tradição, reconhecendo sua judeidade, e concomitantemente dizendo que era ateu, que Moisés era egípcio e não judeu e, ao mesmo tempo, construindo sua liberdade.

Freud, em sua tragédia, mesmo estando a ela agarrado, é verdaderamente alguém que mostra a força, o drama, a potência do fato ao mesmo 
tempo de se apoiar sobre os desejos e as tradições religiosas de seus pais, e concomitantemente construir, com suas tradições, alguma coisa que forçosamente não estava prevista, que não era forçosamente esperada. Assim, não podemos absolutamente dizer que isso lhe fez renegar suas origens - em todo caso eu não o diria, mesmo se alguns o pensam, evidentemente - , mas que lhe permitiu encontrar uma via. Então a psicanálise ela é, em todo caso, um afastamento e uma libertação em relação a isso que alguém recebeu em sua nascença. Assim, encontrar seu desejo é também encontrar-se em relação ao desejo dos outros.

Todas as escolhas estão abertas. Mas essa questão do desejo do analista, isso diz bem por que a análise permanece inventiva, aberta. E que, em suma, ela seja aberta ao que há de vir e a um futuro, como quando dizemos que o Senhor disse a Moisés "Eu sou isso que eu sou" ou bem "Eu serei isso que eu serei" [risos]. É um grande debate, aparentemente é um futuro e não um presente. Bem, resumindo, então são todas essas questões. Mas é o desejo que prevalece. Quer dizer que, basicamente, Lacan encontra sob esse modo na análise um enraizamento pessoal, subjetivo e individual, que ele não pretende eliminar.

Lacan continua alguma coisa que é o drama de todos os etnólogos: todos os etnólogos, sociólogos e todos os trabalhadores nas ciências humanas - há quem leu apenas Lévi-Strauss —, todo mundo, todo o drama deles é: como estudar uma outra cultura ao fazer abstração da sua? O etnólogo ou o etnógrafo ele não é de lugar nenhum, é também alguém que vem de uma cultura, com sua língua etc., e ele estuda uma outra cultura.

Não apenas não há um ponto de vista exterior, científico, terceiro. Isso quer dizer que não se pode extrair de sua própria cultura, porque as ciências humanas não são ciências, ainda que elas tenham uma referência às ciências. E não apenas isso, todos os etnólogos fizeram a experiência, e eles a escreveram, e Lévi-Strauss o primeiro, que chegamos a um país onde não conhecemos a língua e demandamos a esse ou aquele membro da tribo que estudamos "conte-nos, conte-me a história, os mitos etc". Há sempre um momento no qual o informante - que é pago e tudo mais - termina por dizer ao etnólogo o que ele pensa que o etnólogo tem vontade de ouvir. E assim os testemunhos não são exatos.

Então é preciso trabalhar com isso. Isso é próprio das Ciências Humanas. Assim, ao mesmo tempo, tentamos construir modelos e protocolos que tentam ser o mais objetivos possível, quer dizer, fazer mais e mais abstração da parte pessoal de cada um em seus fatores. Exceto que há um momento no qual é 


\section{ENTREVISTA}

preciso interpretar os resultados, qualquer que seja o modo pelo qual eles tenham sido obtidos, incluindo o modo quantitativo e, nesse momento, é o desejo daquele que lê que é colocado em jogo. É aí que a questão do desejo do analista se impõe. E, no fundo, do ponto de vista dos Comitês de Ética, de certa forma é o mesmo tipo de problema. Porque no fundo gostaríamos que o Comitê de Ética tivesse uma posição objetiva, em síntese, que ele se comportasse como um comitê científico natural.

Mas não importa a distância que cada um dos membros tome, e a abertura, apesar de tudo, é um comitê composto por pessoas que são cada uma enraizada, que fizeram trabalhos em todo caso notáveis, que têm experiência profunda e uma capacidade de reflexão, mas são homens que pertencem a uma sociedade e mulheres que pertencem a uma sociedade. Então, eles são levados a tomar decisões, as quais podemos pensar, certa ou erradamente, que mudarão a sociedade, e os farão perder seus próprios parâmetros de referência.

Que os casais homossexuais possam ter crianças, que possamos implantar órgãos arrecadados, a torto e a direito, ou próteses nos corpos humanos (Lindenmeyer, 2017), que possamos fazer o comércio dos órgãos, todas essas coisas - necessariamente seus valores irão vacilar. Como eles irão se referenciar em relação a essa vacilação de seus valores, que tem lugar de todas as formas - porque se não vacilou, isso será inquietante para eles - e que os orienta em direção a um mundo relativamente novo? No fundo, o que eles querem? Qual mundo eles querem? Questão que colocamos de modo claro ou de modo polêmico a todos os Comitês de Ética: "Qual mundo vocês querem? Quais pais vocês querem? Quais crianças vocês querem?”. Então um pouco: "Qual é seu desejo lá dentro? Qual é sua expectativa?".

S.B.: A partir do que dizia anteriormente, poderíamos voltar à questão do superego? Você observou, no seu trabalho sobre o desejo da ética, uma ligação entre o apelo à ética e a questão "o que nós queremos", em relação ao superego?

P.G.: Necessariamente, a renovação do apelo à ética vem em uma situação de crise, isto é, ao mesmo tempo em que se trata de um apelo a uma redefinição de valores - já que sentimos que os valores usuais, habituais oscilam ou já não são percebidos nem com a mesma obviedade nem com a mesma força de antes - e, ao mesmo tempo, há esse ponto de vista de que há uma crise que os faz vacilar. Gostaríamos de ter marcos confiáveis que, no final, nos apaziguassem e evitassem que tivéssemos demais a pensar. 
É como na política: se tomarmos a questão da ecologia, estamos muito claramente, em nosso tempo, em uma posição em que nos perguntamos qual mundo queremos, com a necessidade de hierarquizar as escolhas, de definir prioridades, constatando discordância ou desacordo sobre essas prioridades, tanto no nível nacional como no internacional. Isso que deve ser definido como uma prioridade para preservar nosso modo de vida, porque uma cultura é também um modo de vida, ainda que nem sempre apropriado para outras culturas ou outras nações. Então esse tema entra em um conflito.

Claro, é dificilmente evitável, podemos ver bem na questão do carbono, que estamos prontos para fazer uma série de ações e mudanças, mas se pedirmos a alguns países em desenvolvimento que limitem suas emissões de carbono, isso significaria impedir seu crescimento e mantê-los em estado pré-industrial de pobreza ou crise, o que eles não aceitam. Então, aqui estamos diante de muitos problemas e diante dessas múltiplas desorientações e talvez também podemos estar diante de uma dificuldade para pensar as coisas ao final, diante do fato de que o progresso nos impõe questões e, sobretudo, escolhas. Podemos fazer coisas hoje que não poderíamos fazer antes, as possibilidades aumentaram.

Também medicamente, em termos corporais, poderemos cientificamente fazer coisas que não poderíamos fazer antes. E às vezes isso é muito bom. Afinal, podemos dizer que, em nossas sociedades, nos permitimos cada vez mais, aos homens e às mulheres, ter uma vida completamente inscrita sem ter filhos por exemplo. Logo, sim, é um progresso que muda certo número de coisas e, portanto, temos medo e, assim, há uma inflação ética. Todos querem saber em nome do que estamos agindo e, como resultado, há uma tendência a colocar questões éticas antes de questões científicas, quando há toda uma série de questões científicas clínicas e técnicas, que se devem colocar primeiramente, antes que possamos alcançar a questão ética.

Claro, o que eu disse sobre Lacan e a psicanálise acerca da questão ética é importante, mas sob a condição de situá-la no seu tempo. Pois, em contrapartida, há toda uma prática que obedece a considerações clínicas, científicas e experimentais que não apelam automaticamente à ética como referência. Se um cirurgião ou um médico lava as mãos antes de cada operação, não é apenas por razões éticas, é porque ele sabe o que é uma infecção, ele sabe depois de Pasteur, o que é uma doença nosocomial. Assim, há uma questão de saber, de disseminação do conhecimento. Sua ética é saber se ele leva em conta o saber ou não. Então as coisas são um pouco complexas. E nesta referência à ética, pelas observações que fiz a você, arrisca-se a santificar a ética por si 


\section{ENTREVISTA}

mesma. Mas todas as práticas têm uma ética. Os bandidos têm uma ética, as máfias têm uma ética, as gangues das cidades têm uma ética, então, o fato de reivindicar a ética não é suficiente para justificar por si só uma prática. Portanto, você tem que se perguntar "que ética? ética do que?". O que vem como valor para orientar ou regular uma ação e não apenas o fato de haver valores.

Ter uma ética não justifica por si só e automaticamente comportamentos e posições em nome da ética, pois parece-nos, cada vez mais, que as éticas são diversas. E, além do mais, existem leis por todos os lugares. Em sistemas de corrupção, há uma ética, se não pagarmos, acaba muito mal. Há ética em toda parte, então aqui também não devemos nos questionar sobre a ética como tal, devemos questionar os valores em cujo nome essa ética é implementada.

Tudo isso me fez voltar a posições que você conhece, mas que talvez eu possa retomar aqui, isto é, que a questão da ética só surge quando não sabemos o que fazer. Ou seja, quando há um desconhecido, uma vacilação, uma incerteza sobre as decisões, em relação aos valores que devem ser favorecidos: "o que eu ganho primeiro?". E nesse conflito de interesses, nessas escolhas, vem a questão da decisão. Quem diz "decisão" diz que não estamos em um regulamento, não nos encontramos diante de leis que já estão inscritas, formuladas e que, portanto, tornariam possível saber o que fazer. Nós nos encontramos em situações sem precedentes que supõem que tudo está codificado e que, portanto, presumem uma nova reflexão que deve, após deliberação, apresentar, iluminar a decisão e propor certa hierarquia do que é privilegiado neste ou naquele caso.

C.L.: Talvez uma outra questão que gostaríamos de lhe propor: haveria um elo entre este apelo a uma ética, como instância perante a ciência, isto é, a ética que dita à ciência alguma coisa e não a técnica da ciência que viria interrogar algo sobre a ética? Em caso afirmativo, existiria então um elo entre o mal-estar na civilização e este apelo? Em outras palavras, esse chamado à ética não seria um novo estilo do mal-estar na civilização?

P.G.: Sim. Estou plenamente de acordo contigo. E vemos isso muito bem no campo da medicina, por exemplo no caso de pesquisas sobre o embrião.

C.L.: Um exemplo muito interessante: na China, um pesquisador modificou o DNA de dois embriões humanos, com o famoso cinzel de DNA CRISPR-Case $9^{1}$ independentemente de qualquer decisão do Comitê de Ética. Os acadêmicos se voltaram contra esse pesquisador. Isso levanta a questão:

${ }^{1}$ Ver https://fr.wikipedia.org/wiki/Cas9. 
este romance - que faz parte do imediatismo talvez - a ética não teria que introduzir aí uma dimensão do tempo? Ou é a ciência que impõe seu próprio ritmo, ao qual a ética deve seguir?

P.G.: Quando nos referimos à ética nesse tipo de caso, gostaríamos de ter uma ética que regulasse as coisas. Mas também se percebe historicamente que as mentalidades mudam, que muitas coisas que eram consideradas antiéticas até dez anos atrás, ou um pouco mais, como a pílula anticoncepcional, estão hoje relativamente fora do campo da ética. Eles não têm o caráter dramático do que os seres humanos fazem ou não fazem. Há uma pequena evolução aqui, que é também uma evolução da relação consigo mesmo e da relação de valores em si mesma. A questão da contracepção, do uso da pílula anticoncepcional, também inclui a ideia de que as mulheres podem considerar que seu corpo pertence a elas. Toda pergunta que se pode fazer, que não era tão óbvia antes, desse ponto de vista, coloca em destaque a escolha que uma mulher pode fazer. Em primeiro lugar, não se trata apenas da mãe. Não há dois sexos na humanidade: homens e mães, mas existem também mulheres.

Desse ponto de vista, o fato de dar à luz, isto é, que uma mulher se torne mãe, pode também se opor a uma decisão que envolve o que é ser mãe, assim como uma discussão acerca da família. Ela coloca-se no nível da escolha. Vemos que, às vezes, gostaríamos que as pessoas, em síntese, não escolhessem. E quando elas são colocados em situação de uma escolha que está em suas mãos, isso as angustia ou causa uma série de crises. É verdade que a escolha é angustiante e que, no final, os seres humanos podem esperar não ter que se fazer certo número de perguntas, portanto, não ter que escolher. E, deste ponto de vista, não ter que desejar, no sentido progressivo do desejo. Todo mundo deseja, gostemos ou não. Aí estamos no registro do superego.

Assim, vemos que o desenvolvimento excessivo da ética é o sintoma de um pânico geral, isto é, de uma vacilação de certezas e que, ao mesmo tempo, o desenvolvimento da ética acompanha um desenvolvimento de responsabilidades e escolhas. Quanto mais escolhas temos em nossas vidas — todas as escolhas, por que não incluir a eutanásia —, mais precisamos de ética, isto é, pensar com os outros. A decisão é singular, mas a construção da ética é coletiva, pelo menos em uma comunidade, para tentar orientar essas escolhas. É claro que todas as regressões políticas que estão ocorrendo no mundo, incluindo algumas reivindicações em nosso país — "o aborto deve ser suprimido?" — refletem um pânico regressivo sobre a mudança.

Assim, para voltar à sua pergunta original, eu fiquei um pouco distante dela, ou seja, o que você disse sobre a manipulação do genoma, é 
difícil porque gostaríamos que houvesse certa quantidade de coisas que não acontecem. No mesmo movimento, os pesquisadores têm um movimento de pesquisador: quando pesquisam, não sabem o que vão encontrar e, não sabendo o que vão encontrar, podem cometer erros e, ao mesmo tempo, podem colocar mais e mais em perigo a ideia que temos do nosso meio ambiente ou do humano. Você pode considerar a energia nuclear, que é a melhor e a pior das coisas, há cientistas que se recusaram a vê-la, que têm medo dela, o problema - pode não ser o lugar a evocá-lo — é o aspecto, no fundo, de conquista do mundo e da vida. Estamos em um momento em que há conflitos e lutas que vão além de todos e são extremamente difíceis de parar. Então, é uma questão de ética? Sim. É uma questão de relação de poder? Sim. É verdade que, com as novas personalidades chegando ao poder, é o triunfo do poder sobre a ética. Em outras palavras, o estado de fato e o reconhecimento de que, depois de tudo, as relações somente podem ser relações de força, como, por exemplo, no Brasil, "quero suprimir a floresta e, se você quiser me impedir, você não tem escolha senão entrar em guerra contra mim”. Então, aqui estamos em pura relação de poder.

C.L.: Uma pergunta sobre a ciência e o sujeito. Esse triunfo cientifico que propõe sem cessar reduções que, em algum lugar, dão uma leitura mais e mais mecânica do corpo. Com esses avanços, poder-se-ia dizer que se toca uma essência do corpo, mas da qual se busca um substrato puramente fisicalista e mecanicista e algo que seria governado pela ação e pela reação. O que a psicanálise diria sobre isso? Lacan advertiu, do lado da magia e da religião, em Ciência e Verdade.

P.G.: A ética é a questão do sujeito. Assim que nos perguntamos sobre a questão do sujeito, abrimos automaticamente a questão ética. Quando dizemos para nós mesmos "E o sujeito lá dentro? Quem é ele? O que ele faz? Que lugar lhe damos?" e, ao mesmo tempo, "Que lugar assumimos no que fazemos?", abrimos uma dimensão ética automaticamente. A ciência, enfim, o que Lacan chama de discurso da ciência, ela avança sozinha. Mas, afinal de contas, para o sujeito essa não é, de fato, a sua questão. Essa não é a questão dele. Seja em Biologia, em Física, em todas as suas técnicas, essa não é a questão dele. É um pouco "tudo é possível". O ser humano aceitará ou não as possibilidades oferecidas pelos transhumanistas, ${ }^{2}$ no sentido de que

${ }^{2}$ Ver C. Lindenmeyer, 2017. 
elas sempre afastam os limites do que pode ser considerado humano? Elas vão além deles, eles os atravessam. Se podemos dizer, de um lado, que não é um mundo familiar, uma realidade familiar o que isso implica, ao mesmo tempo, se reconhecerá ali, uma parte dos avanços científicos. Por que há a ciência que conquista, inova, cura, tem os implantes, é uma coisa ótima, realmente grande, mas afasta certo limite do humano. Mas, por outro lado, há sempre o medo de algo, de algo que nos escapa ou de algo que não controlamos. $\mathrm{E}$, nesse momento, a ética volta para nos lembrar que somos humanos e que é o humano que está em jogo. Antes de nos vermos, pensei: o que é ética? Ética é a questão da responsabilidade. A questão da responsabilidade é essencial. Podemos pensar que temos uma responsabilidade abusiva, que assumimos muita responsabilidade e que devemos assumir mais. Porém, a questão da ética sempre vem, como eu disse, "como posso ser responsável? Eu tenho uma responsabilidade? Ou exonero-me de qualquer responsabilidade? Ele tem um problema, eu não me responsabilizo, trago uma prótese como solução". Quando esse problema se torna ético? Quando dizemos a nós mesmos: "eu assumo uma responsabilidade". E, portanto, simplesmente ao assumir uma responsabilidade, isso inclui um efeito de retorno. Posso estar errado. Posso dizer para mim mesmo "eu não deveria ter feito isso". Eu posso me sentir preso nos efeitos de retorno da decisão que tomei. Isso é a ética também. Não é exonerar-se de qualquer responsabilidade. É, ao contrário, tentar aceitar uma responsabilidade com as consequências da responsabilidade que são também: o fracasso, a incerteza, o erro e o desconhecido. Extrair-se o sujeito desse tipo de decisão é problemático.

S.B.: Então, finalmente, se entendermos bem o avanço que o senhor está empreendendo, o objetivo do Comitê de Ética não seria nunca dar uma opinião final? Mas manter a questão?

P.G.: Absolutamente. É perfeitamente justo o que você diz. O Comitê de Ética dá opiniões. Ele dá recomendações, mas ele nunca legisla. E, no nosso país, cabe ao legislador, isto é, à assembleia eleita, saber, de acordo com essas avaliações - que são políticas, conflituosas, societárias em que medida e de que forma levará em consideração suas opiniões e recomendações. É exatamente isso. Quando Simone Weil propôs a lei que permite a interrupção da gravidez, ela sabia que iria propor uma crise, ela sabia que seria difícil votar, mas que haveria uma maioria. Porém, ela decidiu levar ao parlamento a proposta de uma decisão, enquanto ela e muitas mulheres eram a favor. Ela decidiu levar essa decisão ao parlamento 


\section{ENTREVISTA}

que a legislou. Então os Comitês de Ética dão opiniões, eles oferecem recomendações, isto é, tentam elaborar a questão e ir um pouco mais longe na reflexão. E, então, é o legislador quem tem uma série de considerações e de acordo com o que é exigido pela aprovação de uma lei em nosso país, ou seja, a constituição, decide votar. Isso é fundador do Comitê de Ética. É por isso que é chamado Comitê de Ética. E é por isso que, como você disse, ele dá conselhos e recomendações.

O Comitê de Ética permite progressos porque, basicamente, uma lei é mais provável de passar se for apoiada pelas opiniões do Comitê de Ética que pensou, que auditou um número de pessoas, que constrói um argumento, que dá uma opinião. Portanto, suas opiniões teriam a função de preservar um mínimo de coesão social sobre temas que sempre envolvem a ideia que se tem de um ser humano, através de sua família, através de sua sexualidade, pela possibilidade de procriar. E, de certo modo, oferece uma coerência, senão coesão, acerca da sociedade em que vivemos, com opiniões que o Comitê de Ética pode dar. Mas digo bem opinião argumentada, e mais diretamente questões políticas ou sociais que são: o que uma sociedade pode aceitar ou não como uma transformação sem minar sua própria coerência? - ou seja, que não tenha efeitos dissociativos demais. E a ideia que uma sociedade se faz dela mesma — eu falo pela França — isto é, a ideia que temos do que é a nossa república e, portanto, da laicidade à qual estamos ligados, mantém também seu valor. Estamos em um país onde as coisas estão indo devagar, temos problemas para mudar tudo. O Estado tem dificuldade em tomar decisões — finalmente há lobistas — porque as decisões são imediatamente universais e é um pouco complicado. Houve um momento em que o início do aborto - e existem ainda clínicas que se recusam a praticar o aborto, médicos que se recusam a praticar com um direito que é reconhecido... Estima-se que, se eles estão em conflito moral, se eles são levados a tomar decisões com as quais não estão em acordo moral, eles têm o direito de não aplicá-lo. E assim, de repente, havia regiões da França onde não havia clínicas, onde as mulheres poderiam fazer uma interrupção da gravidez e, porque os médicos não a queriam apesar da lei. Essas mulheres foram obrigadas a andar $300 \mathrm{~km}$ em condições desfavoráveis para que se encontrassem na condição de mulheres parisienses, com a necessidade de ir a Londres para fazer uma interrupção da gravidez... Então, isso é algo absurdo. Havia também algumas clínicas laicas, confessionais, que não tinham a mesma informação na data em que era possível praticar um aborto. Assim, os indivíduos, as mulheres se viravam com isso, seja para serem favorecidas 
ou desfavorecidas - isso permanece como áreas de tensões. A lei é feita para preservar essa diversidade? Ou a lei é feita para abolir essas diversidades? Este é um problema político, e nós o vemos muito bem na escola: há um movimento laico que quer suprimir todas as escolas privadas e há escolas confessionais laicas, cristãs, judias, protestantes, muçulmanas. Há sempre um conflito que surge, falo disso porque é bem visível. Então, isso pertence à Câmara dos Deputados. Então, de certa forma, o Comitê de Ética não é tão ruim para isso.

C.L.: Sim, aconteceu, por exemplo, de psicanalistas, fora do Comitê de Ética, assumirem a liderança sobre questões da sociedade, questões políticas, e foram ao Senado testemunhar sobre o casamento homossexual, por exemplo. O que pensar sobre isso?

P.G.: O que deve ser dito é que eles intervêm em seu nome próprio.

C.L.: Eles intervêm em seu nome...

P.G.: Há sempre uma tendência de que eles intervêm em nome da psicanálise, mas nós não concordamos em absoluto entre nós, porque os psicanalistas não são, nós não somos os sacerdotes do simbólico. Nós não somos especialistas do simbólico, de forma alguma. E então você tem que saber um pouco o que você diz. Todos os colegas que têm esse tipo de posição estavam em grande parte equivocados, pelo menos quanto às consequências do desastre clínico que eles previram. Penso em alguém, Jean-Pierre Winter, que pensa que a homossexualidade é quase uma doença psíquica porque está condenada na Bíblia e ele defende o pai de certa maneira. O que ele diz, enfim, clinicamente, está completamente errado. Clinicamente não se sustenta. As pessoas vivem como podem com suas dificuldades. Haverá aqueles que ficarão melhores assim do que do modo contrário. E então antes de se perguntar se os homossexuais irão fabricar doidos, também devemos reconhecer que houve doidos desde 10.000 anos e que as famílias "normais" contribuíram largamente para a questão da transmissão da loucura. Não é um desastre. Isso não significa que não haja na psicanálise elementos de reflexão, bem pelo contrário. $\mathrm{O}$ humano também tem capacidade de resiliência. Ele também tem a capacidade de criar sua própria vida, tem também uma capacidade de renovação - é isso que, efetivamente, conta.

C.L.: Isso coloca uma questão: qual é o lugar da psicanálise? 


\section{ENTREVISTA}

P.G.: A psicanálise se tornou uma referência. No entanto, depende de como se alimenta e como se a usa como referência. Eu faço parte daqueles que pensam que não deve haver um uso indevido da psicanálise; a psicanálise não é um corpo de doutrina. Finalmente não podemos prever. Basicamente, gostaríamos que a psicanálise nos tranquilizasse, mas ela só pode realmente apontar as coisas difíceis. Ao mesmo tempo, ela pode mostrar que o ser humano é também alguém que pode sair, sob certas condições, em uma psicanálise, por exemplo - desde que seja bem conduzida —, não muito mal de situações muito difíceis e muito destrutivas. A verdade é que não sabemos. Se não é profetismo. Um profeta é alguém que anuncia o futuro ou é alguém que faz perguntas? Se vemos quais são as tradições do que é um profeta na Bíblia, vemos que há uma tradição que faz do profeta alguém que anuncia um futuro, mas há outra tradição que faz do profeta aquele que faz perguntas, que incomoda a todos, que perturba a todos. Ele realmente prevê o futuro? Não. Portanto, temos duas relações bastante diferentes.

S.B.: Eu gostaria de voltar ao que disse: "A verdade é que não sabemos".

P.G.: Não é ruim que, em uma sociedade, o que não sabemos esteja em determinado lugar! "Nós não sabemos" é também abertura. É como a vida, existem coisas que sabemos, existem coisas que não sabemos.

C.L.: O último ponto é sobre o futuro. O futuro do "não saber" passará pela ética?

P.G.: Sim, de certa forma. Afinal, os Comitês de Ética se tornam, em países onde existem — há países onde não há nenhum — uma espécie de locais de alerta. Eles têm uma função de alerta. Eles têm uma função de reflexão, não necessariamente de regulação. Por exemplo, a partir do momento em que se trata de aplicar o que é possível, isto é, de estar em uma situação em que se diz "Nós podemos fazer isso, mas nós não fazemos isso". A verdade é que o Comitê de Ética é pensado em uma sociedade com suas diferentes referências - religiosas, seculares, em diferentes modos, em um nível mais relacionado à decisão política. O poder está ligado à pluralidade dessas referências. Tenta-se constituir, se não um discurso comum, pelo menos um debate comum compartilhado sobre essas questões. 


\section{Referências}

Freud, S. (1989). Sur une Weltanschauung. In: Freud, S. Nouvelles conférences d'introduction à la psychanalyse (pp. 211-243). Paris, França: Gallimard. (Trabalho original publicado em 1933).

Guyomard, P. (1992). La jouissance du tragique. Antigone, Lacan et le désir de l'analyste. Paris, França: Aubier.

Guyomard, P. (1998). Le désir d'éthique. Paris, França: Aubier.

Guyomard, P. (2009a). Les enfants ne mentent pas. In J. André, \& C. Chabert (Orgs.), Désirs d'enfant (pp. 123-137). Paris, França: PUF.

Guyomard, P. (2009b). Rien au centre. In P. Aulagnier (Org.), La pensée interdite (pp. 75-91). Paris, França: PUF.

Guyomard, P. (2012). Je vous ai compris. In J. André, \& A. Schniewind (Orgs.), Comprendre en psychanalyse (pp. 131-141). Paris, França: PUF.

Lacan, J. (1986). Le séminaire. Livre VII. L'éthique de la psychanalyse. Paris, França: Seuil. (Trabalho original publicado em 1959-1960).

Lindenmeyer, C. (Org.) (2017). L'humain et ses prothèses. Savoirs et pratiques du corps transformé. Paris, França: CNRS éditions.

Citação/Citation: Leclerc, C., \& Bergheimer, S. (2019, dez.). A psicanálise e a perspectiva ética na contemporaneidade: entrevista com Patrick Guyomard. Revista Latinoamericana de Psicopatologia Fundamental, 22(4), 687-709. http://dx.doi. org/10.1590/1415-4714.2019v22n4p687.3.

Editoras/Editors: Profa. Dra. Andréa Máris Campos Guerra e Profa. Dra. Cristina Lindenmeyer

Recebido/Received: 23.9.2019 / 9.23.2019 Aceito/Accepted: 23.10.2019 / 10.23.2019

Copyright: (C) 2009 Associação Universitária de Pesquisa em Psicopatologia Fundamental/ University Association for Research in Fundamental Psychopathology. Este é um artigo de livre acesso, que permite uso irrestrito, distribuição e reprodução em qualquer meio, desde que o autor e a fonte sejam citados / This is an open-access article, which permits unrestricted use, distribution, and reproduction in any medium, provided the original authors and sources are credited. 


\section{ENTREVISTA}

\section{Christopher Leclerc}

Psicólogo; Doutorando, CRPMS, Université Paris VII Diderot, Université de Paris (Paris, França).

christopherleclerc@gmail.com

https://orcid.org/0000-0002-9822-711X

\section{Sophie BergheIMER}

Psicóloga; Doutoranda, CRPMS, Université Paris VII Diderot, Université de Paris (Paris,

França); Doutoranda na Universidade de São Paulo - USP (São Paulo,SP, Br), em cotutela.

s_bergheimer@hotmail.fr

https://orcid.org/0000-0003-0414-3669

This is an open-access article, which permits unrestricted use, distribution, and reproduction in any medium for non-commercial purposes provided the original authors and sources are credited.

Rev. Latinoam. Psicopat. Fund., São Paulo, 22(4), 687-709, dez. 2019 